JOSÉ SAED AYUB

\title{
Poemas
}

\author{
José Saed Ayub
}

\section{ARS LONGA, VITA BREVIS}

Dos cuerpos enlazados domestican la eternidad

VicEnTE HuidobRo, Temblor de cielo

ars longa

vita

brevis

Cursivas imperfectas, el sello de tu dorso.

La vida es breve, dices, el tiempo un mal payaso.

En cambio largo el arte: baúl roto, rotas redes.

No quiero la corona franciscana ni la cínica panza entre tirantes, no vuelo cinco estrellas ni hotel primera clase.

No estar contigo es medida del abismo proyecto de paisajes quizá de. 
Garantía de viajes sin retorno somos pactos sin firma sin plan, ni luz, ni guía. Arco iris somos, otoño que desciende, se eleva

y precipita.

Me alargo en levedad de colibrí me abrevo entre tus labios, me amparo en tu sonrisa me alojo en la tormenta de tu pelo, en su amenaza de naufragio.

Sin embargo dos cuerpos enlazados domestican la eternidad.

Dos cuerpos enlazados la gravidez la levedad, la sordidez

la soledad.

Solidez de la tempestad.

Dos cuerpos enlazados desafian la eternidad.

No nos vayamos del todo, clausuremos la mañana.

Seamos

porción de paraíso

vuelo de noche,

larga estampa.

Instante sostenido por botones de agua. 
JOSÉ SAED AYUB

Fracción de escalofrío, tatuaje inexorable de trazos dibujados en tu espalda.

\section{MEDIOCRE CON ESTRÉS Y DE CORBATA}

Mediocre con estrés, puntual y de corbata por el tráfico y la lluvia enfurruñado de camisas planchadas entre días me vuelvo a cada paso de vestir.

Cada fin de semana pordiosero me convierto en rebaño de historias en serie o en futbol.

Es domingo y ya me duele el lunes. Me torno criminal sin quehaceres o hater. Me purifico en sudadera, me asesino las uñas y la barba.

Aún me queda tiempo de extrañarte.

No soy más que este cualquiera que paga la hipoteca, ni que los novios que pasan su domingo en Coyoacán; soy este cuerpo lento, cansado de optimismos, este bigote ralo, el dolor, esta vergüenza, esta sonrisa amarga que siempre te sonríe. 